\title{
Impact of the Prospera program in Oaxaca, Veracruz and Istmo based on autonomous income
}

\section{Impacto del programa Prospera en Oaxaca, Veracruz e Istmo basado en el ingreso autónomo}

\author{
VÁZQUEZ-ELORZA, Ariel*†, CASTAÑEDA-BERNAL, Xóchitl Yolanda and ACEVES-JIMÉNEZ, \\ Sandra Goreti \\ Centro de Investigación y Asistencia en Tecnología y Diseño del Estado de Jalisco A.C (CIATEJ-CONACYT), Guadalajara, \\ Jalisco, México. Av. Normalistas \#800, Colinas de la Normal, 44270, Guadalajara, Jalisco México.
}

ID $1^{\text {st }}$ Author: Ariel, Vázquez-Elorza / ORC ID: 0000-0002-6710-8935

ID 1 ${ }^{\text {st }}$ Coauthor: Xóchitl Yolanda, Castañeda-Bernal / ORC ID: 0000-0001-8921-1004

ID $2^{\text {nd }}$ Coauthor: Sandra Goreti, Aceves-Jiménez / ORC ID: 0000-0002-6104-8425

DOI: $10.35429 / J B S .2020 .17 .6 .6 .17$

Received February 01, 2020; Accepted April 01, 2020

\begin{abstract}
Mexico concentrates the marginalization in the southeastern states, to counteract this problem the federal government implemented several universal social programs, including Prospera. This research analyzes the impact generated among the beneficiaries of the Prospera Program based on income from work, and the variables of education, health, food security, both at the state level in Veracruz and Oaxaca and in the Istmo region that integrate both states. The Propensity Score Matching method was used to assess the impacts on labor inclusion that have those who receive the program, in contrast, with those who do not receive federal support. In addition, through the Analysis of Main Components, we related the productive and marginalization variables to find the characteristics of the study population. The results show that the Prospera program does not have a significant impact on the per capita income of the head of household. However, quintiles two and five have greater negative effects for the population from the Istmo. It is essential to revalue the Prospera Program strategy and incorporate more rigorous administration to have a positive impact for the rural population dedicated to agricultural activities.
\end{abstract}

Marginalization, impact assessment, Istmo region

\section{Resumen}

La marginación en México se concentra en los estados del sur sureste, para contrarrestar esta problemática el gobierno federal implementó diversos programas sociales universales, entre ellos, Prospera. La presente investigación analiza el impacto generado entre los beneficiarios del Programa Prospera sobre la base del ingreso por concepto de trabajo, y las variables de educación, salud, seguridad alimentaria, tanto a nivel estatal en Veracruz y Oaxaca como en la región del Istmo que integran ambos estados. Se utilizó la metodología Propensity Score Matching para evaluar los impactos en materia de inclusión laboral que tienen quienes reciben el programa, en contraste, con aquellos que no reciben el apoyo federal. Además, mediante el Análisis de Componentes Principales se relacionaron las variables productivas y de marginación para identificar las características de la población en estudio. Los resultados evidencian que el programa Prospera no tiene un impacto significativo en los ingresos per cápita del jefe de hogar. No obstante, los quintiles dos y cinco presentan mayores efectos negativos para la población beneficiada en el Istmo. Resulta fundamental revalorizar la estrategia del Programa Prospera e incorporar elementos de administración y eficiencia más rigurosos para obtener impactos positivos para la población rural dedicada a las actividades agrícolas.

Marginación, evaluación de impacto, región del Istmo

Citation: VÁZQUEZ-ELORZA, Ariel, CASTAÑEDA-BERNAL, Xóchitl Yolanda, ACEVES-JIMÉNEZ, Sandra Goreti. Impact of the Prospera program in Oaxaca, Veracruz and Istmo based on autonomous income. Journal of Business and SMEs. 2020. 6-17: 6-17.

*Correspondence to the Author (Email: avazquez@ ciatej.mx)

$\dagger$ Researcher contributing first author. 


\section{Introduction}

The south-southeast region of the United Mexican States (Mexico) is characterized by maintaining high levels of marginalization and social backwardness, concentrating on the states of Veracruz, Oaxaca, Guerreo and Chiapas according to the poverty and social assessment reports of the National Evaluation Council. of the Social Development Policy (CONEVAL, 2018a). Paradoxically, these states also concentrate the greatest natural wealth of national flora and fauna. In the case of Veracruz and Oaxaca, there is a region surrounded by great cultural, gastronomic and social traditions that is called the Isthmus, made up of 78 municipalities from both states. In addition to the above, it is also relevant to note that a project related to the modernization and construction of a trans-isthmic route (maritime and land) in the Atlantic Ocean and the Gulf of Mexico has been visualized by the federal government. For this reason, in 2017 a National Project called "Logistics Platform as a trigger for development in the Isthmus of Tehuantepec" was presented, where the Center for Research in Geography, among other institutions attached to the National Council of Science and Technology (CONACYT), participates and Geomatica (CENTROGEO) and, the Center for Research and Assistance in Technology and Design of the State of Jalisco (CIATEJ).

From this perspective, it is essential to generate key information that shows whether the social programs implemented by the federal government have really had benefits in society. In addition, it is necessary to pay for elements that help to focus the design and implementation of public policies for the social and economic development of a population. In this case, the Isthmus region is characterized by achieving poor human and socioeconomic development indicators, well below the national average. The socioeconomic particularities in the population as a whole present cultural, productive and idiosyncratic similarities and, inland, highlight the differences between localities, rural and urban populations; to cite an example: between $67.61 \%$ and $84.50 \%$ of the population receive income below 2 minimum wages, predominantly territories inhabited by indigenous populations of Olmec, Tuxtlas and Sierra Norte origin.
Most of the population engaged in agricultural activities are subsistence, distinguishing between livestock production on the coasts of both states (Veracruz and Oaxaca) and, the agricultural sector concentrating towards the ends of the Isthmus territory, although in a more distributed. Let us consider some figures to account for the situation of the population, the average percentage of the population aged 15 years or over is illiterate, which represented $14.31 \%$ in 2015 , in the same way $14.89 \%$ are occupants of houses without piped water service, according to data from the National Population Council (CONAPO, 2015b).

\section{Referential framework}

There are countries in Latin America that have undertaken social actions and programs to tackle poverty, highlighting Argentina, Brazil, Chile, Costa Rica, among others. (Raczynski, 1995), carried out a study on social programs in the four countries and highlighted eight general criteria that still prevail today. Next, two that govern the research context of this work are described, which are:

\begin{abstract}
"The strategy to fight poverty is not improvised nor can it consist of a sum of isolated social programs." "Poverty reduction is a long-term task that requires adequate economic policies geared towards growth and the creation of productive employment opportunities, a national tradition of investment in basic social services (health, nutrition, education) and specific targeted social programs to particularly vulnerable localities (geographical areas) and / or social sectors and in which the welfare approach (direct transfer of income to people) is rather an exception than the rule "(Raczynski, 1995: 34-35).
\end{abstract}

According to the United Nations Organization (Ramcharan 2004, pp 5-10), in general, the concept of poverty refers to the limited possibilities of obtaining well-being, that is, to the restricted abilities to access a good state physical, derived from the lack of disposition of economic resources that play a role in the causal chain that leads to a low level of well-being. Furthermore, it is explained that from a "capacity" approach, poverty can be defined as the lack or insufficiency of the realization of certain basic freedoms, such as the freedoms to avoid hunger, disease, illiteracy, etc. (Ramcharan, 2004).

VÁZQUEZ-ELORZA, Ariel, CASTAÑEDA-BERNAL, Xóchitl Yolanda, ACEVES-JIMÉNEZ, Sandra Goreti. Impact of the Prospera program in Oaxaca, Veracruz and Istmo based on autonomous income. Journal of Business and SMEs. 2020 
Regarding the provisions of the World Bank (World Bank, 2018b, 2018a), he points out that to understand poverty, it is necessary to consider a multidimensional perspective that allows integrating not only lack of income and consumption; It is necessary to consider the educational level, the unsatisfactory results in health and nutrition issues, the lack of access to basic services, as well as the knowledge of the environment (identified or not as dangerous).

At the national level, CONEVAL ${ }^{1}$ establishes that the concept of poverty in its broadest sense refers to living conditions that violate people's dignity, limiting their fundamental rights and freedoms, also preventing the satisfaction of their basic needs and making it impossible its full social integration (CONEVAL 2018b: 23). From a multidimensional perspective, it is established that the term "poverty" is related to a series of deprivations defined in multiple domains; such as the lack of opportunities to participate in collective decisions, the lack of resource appropriation mechanisms or the ownership of rights that allow access to physical, human or social capital, among others.

Considering a multidimensional perspective, Mexico through CONEVAL established since 2009 a methodology to measure poverty levels at the national level, based on the nine basic indicators established in article 36 of the General Law of Social Development: I) Income per capita current; II). Average educational backwardness at home; III). Access to health services; IV). Access to social security; V). Quality and spaces of decent and decent housing; SAW). Access to basic services in decent and decent housing; VII). Access to nutritious and quality food; VIII). Degree of social cohesion, and IX). Degree of accessibility to paved road (Chamber of Deputies 2004; CONEVAL 2018b; Gonzalo, Jiménez, and Fiorella 2018).

\footnotetext{
1 Decentralized public body of the Federal Public Administration, with autonomy and technical capacity to generate the measurement of poverty in Mexico.
}

For Gonzalo, Jiménez, and Fiorella (2018: 12), the set of the nine indicators have allowed the identification of three relevant analytical aspects for the study of poverty; the first is associated with well-being, based on the satisfactors that can be acquired through the monetary resources of the population; the second to the fundamental rights of people in matters of social development, and the third to relational and community aspects that are expressed territorially. According to what is established on its official website, the results presented by CONEVAL, on a biennial basis, represent an information base on which decisions can be made to face the situation of poverty in the nation (CONEVAL, 2016). However, in this situation it is essential that the beneficiaries of the Program internalize the need to generate and find work opportunities endowed with decent income, so that the delivery of support does not become a habit or dependency.

Despite the good intentions that national governments have to eradicate poverty, it has been shown that the impacts have not yet managed to reduce it in a generalized and sustained manner. In this context, this research work aims to demonstrate that despite the effort of the federal government in the implementation of public policies of the Prospera program ${ }^{2}$, it has not been possible to increase the level of autonomous income, much less improve the standard of living of the population, mainly in the states of Oaxaca, Veracruz and the Isthmus region of both states.

\footnotetext{
2 This Program began on August 8, 1997 with the name of Education, Health and Food Program (PROGRESA). During 2002, it was transformed into Oportunidades with coverage to the 32 states of the country. Subsequently, on September 5, 2014, it was strengthened and transformed into PROSPERA (Social Inclusion Program), in the Secretariat of Social Development, now the Secretariat of Well-being. On Prospera's official website, it is stated that "it is a program [...], which, through two schemes: with coresponsibility and without co-responsibility, provides resources to almost 7 million Mexican families to strengthen their diet, health and education" At the same time, the Program "links [...] with productive projects, labor options and financial services" (Secretaria del Bienestar, 2019).
}

VÁZQUEZ-ELORZA, Ariel, CASTAÑEDA-BERNAL, Xóchitl Yolanda, ACEVES-JIMÉNEZ, Sandra Goreti. Impact of the Prospera program in Oaxaca, Veracruz and Istmo based on autonomous income. Journal of Business and SMEs. 2020 


\section{Methodology}

The present investigation analyzes the impact generated among the beneficiaries of the Program considering the income from the concept of work, and the variables of education, health, and food security, both at the state level in Veracruz and Oaxaca and in the Isthmus region that make up both states.

It is important to highlight that for the development of this study, the studies carried out (Ceron and Hernández, 2017) who analyzed whether Prospera (formerly Opportunities) "promote the creation of income from productive activities that contribute to overcoming state of poverty and vulnerability in which millions of families live "(Ceron and Hernández, 2017: 406).

The territories under study have high levels of poverty and marginalization, in addition to high levels of economic, social and environmental vulnerability, according to the results of the National Water Commission (CONAGUA, 2015) and the National Population Council (CONAPO, 2015a). For this reason, it was decided to contrast both states (Oaxaca and Veracruz) with the Isthmus region that includes 78 municipalities.

The Propensity Score Matching (PSM) ${ }^{3}$ technique evaluates the impacts on job inclusion that those who receive the program have, in contrast to those who do not receive federal support. It is intended to demonstrate that despite the effort of the federal government in the implementation of public policies of the Social Program (Prospera) it has not been possible to fundamentally increase the level of labor income, much less improve the population's standard of living.

\footnotetext{
${ }^{3}$ The PSM technique is one of the methodologies that the
World Bank recommends for conducting social impact

3 The PSM technique is one of the methodologies that the
World Bank recommends for conducting social impact assessment studies.
}

The investigation considered different official sources with open access in Mexico. Firstly, for indices of the National Population Council, the Agro-Food and Fisheries System of the Ministry of Agriculture and Rural Development, the National Water Commission were used. Secondly, for the empirical study to measure the impact of the Prospera Program in the territories, the National Household Income and Expenditure Survey (INEGI-ENIGH, 2016) was used, which "contributes to the elopment of the country, since it allows the to have a better knowledge of reality to resure 2016: 8). This survey generates various databases, of which the following were combined: households, population, jobs, income and concentrate, following the study by Cerón \& Hernández (2017).

\section{Propensity Score Matching Econometric Model}

The PMS "is the conditional probability of allocation to a particular treatment given a vector of observed covariates" (Rosenbaum \& Rubin, 1983, 1984: 41). This technique allows capturing the effects of different observed covariates $(\mathrm{X})$ on the participation of an index, in this case, it helps to analyze the impact that Prospera has contributed to the population as an approximation to the problem of estimating the distribution of labor income between the beneficiaries of the Program (control group), in contrast, with those who do not receive it atment group), fundamentally distinguishing evel both in the states of Veracruz and Oxaca, specifically in the Isthmus regions. important outstanding works that of Trivedi, 2005. Cerón \& Hernández, 2017; Chen et al., 2006; Jalan \& Ravallion, 2003; Rosenbaum \& Rubin, 1983a, 1983b. For the development of the methodology, the majority will be based on the conceptual basis developed by the latter authors, as they are considered very consistent with the study of the Program in the Mexican case. 
Rosenbaum \& Rubin (1983a: 2) point out in the study that they carried out that, "the $\mathrm{N}$ units are seen as a simple random sample of some population, and the quantity to be estimated is the average effect of the treatment, defined as:

$E(r i)-E(r 0)$ population.

Where $E($.$) denotes expectation in the$

On the other hand, Cerulli (2015: 78), citing Rosenbaum \& Rubin (1983a, 1984), determine that "the propensity score is the conditional probability of receiving the treatment, given the variables $\mathrm{x}$ of confusion. Curiously, since D is binary", in this case those who receive the Program (one), unlike those who do not receive it (zero), the following equality applies:

$p(\boldsymbol{x})=\operatorname{Pr}(D=1 \mid \boldsymbol{x})=E(D \mid \boldsymbol{x})$

For their part, Cerón \& Hernández (2017: 71) mention that "the average estimate of the results of a program is shown by equation 3 , where $\pi \mathrm{i}$ is the result of comparisons of the causal effects.

$\pi i=\mathrm{E}[Y i(1) / \mathrm{T}(i)=1]-[Y i(0) / \mathrm{T} i=0]$

The determination of the average effect, in this case, has the complication that an individual cannot be evaluated before and after, since he only owns the Program at a moment of time in the ENIGH, therefore, the selection process is carried out including variables $\mathrm{x}$ with observable characteristics.

$E[Y i(0)-Y i(1)]=E[Y i(0) \mid T i=0, \mathbf{x}]-E[Y i(1) \mid T i=1, \mathbf{x}]$

Cerón \& Hernández (2017: 71) establish that "the hypothesis that an individual or family has the same probability of being located in any of the groups, defined as conditional independence", whose equation is represented as follows:

$E[Y i(0), Y i(1) \mid T i, \mathrm{X}]$ y $E[Y i(0) \mid T i=0, \mathbf{x}]=E[Y i(1) \mid T i=1, \mathbf{x}](5)$

Cerulli (2015: 78), indicates that The PSM "has two important properties that account for its attractiveness: the balancing and nonconfounding properties". a) Rolling properties. The author points out that the "Balance of confounding variables, given the propensity score: if $\mathrm{p}(\mathrm{x})$ is the propensity score $[\ldots]$ which implies that, conditionally on $\mathrm{p}(\mathrm{x})$, the treatment and the observables are independent ", so:

$\mathrm{D} \perp \boldsymbol{x} \mid p(\mathbf{x})$

For their part, Cerón \& Hernández (2017: 72) describe that "for each estimated probability for individuals in the treatment group, there is a similar probability in the control group".

$E[Y i(0), Y i(1) \mid T i, \mathrm{X}]$ y $E[Y i(0) \mid T i=0, \mathbf{x}]=E[Y i(1) \mid T i=1, \mathbf{x}]$

b) Conditional independence. According to Khandker et al., (2009: 55) "Conditional independence establishes that, given a set of observable covariates $\mathrm{X}$ that are not affected by treatment, the potential results $\mathrm{Y}$ are independent of treatment allocation T." Therefore, $\mathrm{Y}_{\mathrm{i}}^{\mathrm{T}}$ represents the results for the participants and $\mathrm{Y}_{i}^{\mathrm{C}}$ the results of for the non-participants, conditional independence implies:

$\left(Y_{i}^{T}, Y_{i}^{C}\right) \perp T \mid x_{i}$

In this way it is possible to calculate the average impact of the treatment. Following Cerón \& Hernández (2017: 72), equation 7 "shows the average effect of the treatment obtained by the difference between the average result of the treatment group and the control group".

$A T E=E\{E[Y(i) 1 \mid T i=1, p(\mathbf{x} i)]-E[Y(i) 0|D i=0, p(x i)| T i=1]$

According to Abadie et al., (2004: 301) the coincidence estimator: average treatment effect for the weighting matrix treated with inverse variance (SAAT) is expressed as follows ${ }^{4}$ :

$\hat{V}^{\text {sample }, t}=\frac{1}{N_{1}^{2}} \sum_{i=1}^{N}\left\{W_{i}-\left(1-W_{i}\right) K_{M}(i)\right\}^{2} \hat{\sigma}_{W i}^{2}\left(X_{i}\right)$

\footnotetext{
4 For more detailed information use the text: Implementing matching estimators for average treatment effects in Stata (Abadie et al., 2004).
}

VÁZQUEZ-ELORZA, Ariel, CASTAÑEDA-BERNAL, Xóchitl Yolanda, ACEVES-JIMÉNEZ, Sandra Goreti. Impact of the Prospera program in Oaxaca, Veracruz and Istmo based on autonomous income. Journal of Business and SMEs. 2020 
Treatment variable. To estimate the impact, a dummy variable was considered where the Heads of Household benefited Yi (1) and Heads of Household not benefited Yi ( 0 . The scope of the analysis is focused on the states of Veracruz and Oaxaca and, the Isthmus region between both federal entities In addition, the population that was analyzed corresponds to the territories indicated in Annex 1, also indicating households with an expansion factor.

Explanatory variables. They were obtained after making correlations of those indicators that responded to the objective of this research and correspond to the following: heads of households who make expenses without a prescription, head of household, head of household, total number of female residents, ethnicity, education without primary education complete, complete primary, number of hours of work per week, food security, light food insecurity, moderate food insecurity, severe food insecurity, estimation of food expenses, first cause of disability due to illness.

Response variable. Monthly family income per capita as a product of employment from work (in pesos).

It is important to point out that the comparisons between the states of Oaxaca, Veracruz and the Isthmus were carried out with the state municipal representations and by 32 and the 78 municipalities in the Isthmus (INEGI-ENIGH, 2016).

\section{Principal component analysis}

It should be noted that in parallel to the analysis of the Prospera impact evaluation, those indicators related to human development, agricultural, livestock and forestry production were also analyzed in a multifactorial way, mainly for the 78 municipalities of the Isthmus. It is proposed to establish a new holistic vision among the regional characteristics of the population through the Principal Component Analysis with information bases of the National Population Council (CONAPO, 2015a) within the framework of the "Logistics Platform as a trigger for development in the Isthmus "With the direction of the Center for Research in Geography and Geomatics (CENTROGEO) and Center for Research and Assistance in technology and Design of the State of Jalisco (CIATEJ).
The works developed by Farrell et al., (1999: 6), cited by Echeverri et al., (2003), try to find an analysis methodology on territorial (rural) development; for its part, the strengthening of human capital is also identified in a country as growth trends (Barro, 1991; Hanushek \& Kimko, 2000). The analyzed information was obtained from different official sources such as the National Population Council, the Agri-Food and Fisheries System of the Secretary of Agriculture and Rural Development, the United Nations Development Program and the National Institute of Statistics and Geography.

The principal component analysis model methodology was carried out as follows. The set and dimensionality of the information base referring to the agricultural, forestry sector was linked (correlated) with variables on marginalization, lag, income and HDI among the municipalities of the Isthmus by using the Principal Component Analysis (ACP) model to group strata with similarities between the municipalities and differentiated between them. Four components were obtained that explain $73.66 \%$ of the variability of the information. Chi-square hypotheses and their significance $\mathrm{p}$ $=0.000$ were tested. Subsequently, using the stratification methodology of Dalenius \& Hodges (1959), we explored minimizing the variance of the four components obtained. With this, heterogeneous groups are stratified between them and homogeneous among themselves. Subsequently, the components were correlated between the variables of the municipal territories to generate differentiated groups to group them.

When comparing the year 2016 on poverty in Mexico, a decrease in the population is observed with respect to the year 2014 that totaled 1.9 million Mexicans; however, in states such as Campeche, Colima, Chiapas, Oaxaca and Veracruz, an increase can be identified. In the states of Veracruz and Oaxaca it is evident that the average age of heads of household, of the general population, fluctuates between 44 and 48 years. 
The first quintile in both states program beneficiaries receive an average per capita income of \$ 699.22 and the fifth quintile \$ 541.99 pesos quarterly; total per capita income of $\$ 3,394.96$ and $\$ 19,713.13$ pesos (current), respectively. In the case of the Isthmus region, the average age is between 43 and 47 years; Prosper per capita income for the first quintile is $\$ 717.21$ and the fifth quintile corresponds to \$ 571.02; total per capita income of \$2,621.97 and $\$ 22,483.55$ pesos (current), respectively (See Table 1).

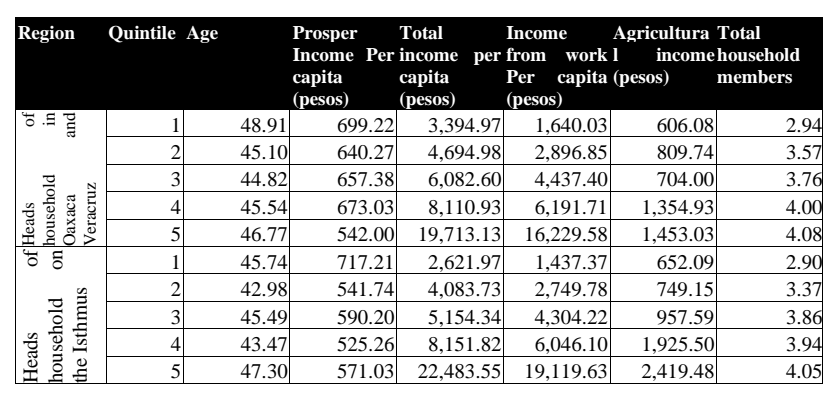

Table 1 Characteristics of the income of the population in Oaxaca, Veracruz and Isthmus

Source: own elaboration based on data from INEGIENIGH (2016)

Table 2 shows the results of the estimates of the effect of the average treatment in the treated group using the closest neighbor coincidence in the case of the population benefiting from the Prospera program on total autonomous (labor) income per capita. The weights in the results (expansion factor) were used. In addition, the population was classified into quintiles considering the 2016 quarterly current income.

\begin{tabular}{|c|c|c|c|c|c|c|}
\hline \multirow[t]{2}{*}{ Zone } & Indicator & 1 & & 23 & 4 & 25 \\
\hline & ATT & -826.188 & -598.144 & -847.441 & $-1,779.686$ & $-3,267.333$ \\
\hline \multirow{3}{*}{$\begin{array}{l} \\
\\
\end{array}$} & $\mathrm{t}$ & $(\mathrm{t}=-3.930)$ & $(\mathrm{t}=-1.776)$ & $(\mathrm{t}=-2.658)$ & $(\mathrm{t}=-3.782)$ & $(\mathrm{t}=-1.778)$ \\
\hline & SAAT & -446.270 & $-1,174.493$ & $-1,155.988$ & $-1,593.721$ & $-4,798.494$ \\
\hline & $\begin{array}{l}\text { Desv } \\
\text { Std., }\end{array}$ & $\begin{array}{l}(129.39) \\
(0.001)^{*}\end{array}$ & $\begin{array}{r}(192.083) \\
(0.000)^{*}\end{array}$ & $\begin{array}{r}(215.465) \\
(0.000)^{*}\end{array}$ & $\begin{array}{r}(345.887) \\
(0.000)^{*}\end{array}$ & $\begin{array}{r}(1,159.548) \\
(0.000)^{*}\end{array}$ \\
\hline & $P>|z|$ & & & & & \\
\hline \multirow{5}{*}{ בี } & ATT & -603.183 & -448.671 & $-1,169.931$ & $-1,375.706$ & $-1,466.117$ \\
\hline & $\mathrm{t}$ & $(\mathrm{t},-0.970)$ & $(\mathrm{t},-0.638)$ & $(\mathrm{t},-1.125)$ & $(\mathrm{t},-0.483)$ & $(\mathrm{t},-0.224)$ \\
\hline & SAAT & -42.135 & $-1,685.776$ & $-1,059.066$ & $-1,577.135$ & $-4,937.681$ \\
\hline & Desv & (467.883) & $(577.854)$ & (443.504) & (1102.912) & $(2049.092)$ \\
\hline & $\begin{array}{l}\text { ttd., } \\
\text { P>|z| }\end{array}$ & $(0.928)$ & $(0.004)^{*}$ & $(0.017)^{*}$ & & $(0.016)^{*}$ \\
\hline
\end{tabular}

Table 2 Impact of the Prospera program on autonomous income in Veracruz, Oaxaca and Isthmus

Source: own elaboration based on the Propensity Score Matching (PSM) technique with data from the INEGIENIGH (2016)

\footnotetext{
5 The classification of quintiles was generated on the basis of the current income that sums income from work, those from rents, transfers, rental estimation and other income INEGI-ENIGH (2016).
}

The outputs show that the Prospera program does not have a significant impact on the per capita income of the head of household according to the closest neighbor matching method $(\mathrm{t}=-3,930)$, in the case of quintile 1 (Q1). The average treatment of treaties (ATT) in autonomous per capita income (labor) is reduced by $-826,188$ pesos with respect to those who are beneficiaries of the Prospera Program. On the other hand, it carried out the study of the coincidence estimator: average treatment effect for the weighting matrix treated with inverse variance (SAAT) whose results support the negative effect that Prospera beneficiaries have, in contrast, with that non-beneficiary population. It is observed that the Q2 and Q5 quintiles present greater negative effects for the beneficiary population in the Isthmus and whose values are statistically significant (1,685,776 and $-4,937,681$, respectively). The results show that in general there are economic and, therefore, social costs in the population benefiting from the Prospera program in the states of Veracruz, Oaxaca and the Isthmus region. In this context, it is essential that the federal government stop not only evaluating social programs, but also operationalizing new actions for an efficient, effective, and social economy government and administration that really positively impacts society with its decisions.

The official and freely accessible information, referring to the 78 municipalities of the Isthmus region, on general socioeconomic issues is presented in Table 3. An important percentage of the population living in rural areas is evident, $61.88 \%$ on average; the population without education and without piped water combined $14 \%$ although with a standard deviation of $6.1 \%$ and $13.93 \%$ respectively.
VÁZQUEZ-ELORZA, Ariel, CASTAÑEDA-BERNAL, Xóchitl Yolanda, ACEVES-JIMÉNEZ, Sandra Goreti. Impact of the Prospera program in Oaxaca, Veracruz and Istmo based on autonomous income. Journal of Business and SMEs. 2020 


\begin{tabular}{|c|c|c|}
\hline Analysis variable & Mean & $\begin{array}{l}\text { Standard } \\
\text { deviation }\end{array}$ \\
\hline $\begin{array}{l}\% \text { of Population aged } \\
15 \text { years or more } \\
\text { illiterate }(2015)\end{array}$ & 14.31 & 6.51 \\
\hline 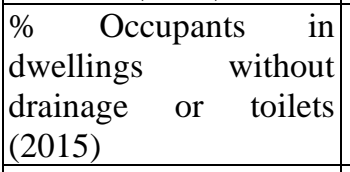 & 3.96 & 4.42 \\
\hline $\begin{array}{l}\% \text { Occupants in homes } \\
\text { without electricity } \\
(2015)\end{array}$ & 2.71 & 2.78 \\
\hline $\begin{array}{l}\text { \% Occupants in houses } \\
\text { without piped water } \\
(2015)\end{array}$ & 14.89 & 13.93 \\
\hline $\begin{array}{l}\text { \% Occupants in houses } \\
\text { with dirt floors }(2015)\end{array}$ & 8.62 & 9.43 \\
\hline $\begin{array}{l}\% \quad \text { Population in } \\
\text { localities with less than } \\
5,000 \quad \text { inhabitants } \\
(2015)\end{array}$ & 61.88 & 36.08 \\
\hline $\begin{array}{l}\% \\
\text { population }\end{array} \begin{array}{r}\text { Employed } \\
\text { income of up to } 2 \\
\text { minimum } \\
(2015)\end{array}$ & 56.22 & 13.69 \\
\hline $\begin{array}{l}\text { Annual per capita } \\
\text { income (PPP dollars) } \\
2010\end{array}$ & $8,232.61$ & $3,950.72$ \\
\hline $\begin{array}{ll}\begin{array}{l}\text { Education } \\
(2010)\end{array} & \text { Index } \\
\end{array}$ & 0.55 & 0.10 \\
\hline Income index (2010) & 0.62 & 0.07 \\
\hline Health index (2010) & 0.83 & 0.06 \\
\hline$\%$ of Poverty (2010) & 68.73 & 16.96 \\
\hline $\begin{array}{l}\text { Forest activity area } \\
(2016)\end{array}$ & 597.28 & $1,684.74$ \\
\hline $\begin{array}{l}\text { Total value of } \\
\text { Agricultural } \\
\text { production (2017) }\end{array}$ & $30,084,441.70$ & $82,642,946.92$ \\
\hline $\begin{array}{l}\text { Total value of } \\
\text { livestock production } \\
\text { (2017) }\end{array}$ & $373,003.39$ & $783,596.40$ \\
\hline \multicolumn{3}{|c|}{$\begin{array}{l}\text { Note: The value of the agricultural sector is made up of } \\
\text { the main analysis crops: mango, lemon, sorghum, } \\
\text { orange, coffee, papaya, sesame, agave, watermelon, } \\
\text { meat, wax, cattle, egg, plate, milk, honey from the } \\
\text { region of the Isthmus. }\end{array}$} \\
\hline
\end{tabular}

Table 3 Descriptors of the variables under study in the municipalities of the Isthmus

Source: own elaboration based on data from CONAPO (2015b), INEGI (2015), UNDP (2015), SADER-SIAP (2018)

Table 4 shows the relevance of productive activities and income on the regions that comprise the Isthmus region. In particular, in the livestock sector the Olmec, Isthmus and Papaloapan regions stand out, as well as in the agricultural and forestry sector. On the other hand, in terms of income, on average, the Olmec region presents the highest level, followed by the Isthmus and the Mountains.

\begin{tabular}{|c|c|c|c|c|c|}
\hline $\begin{array}{l}\text { Sub reg } \\
\text { of } \\
\text { Isthmus }\end{array}$ & gions & $\begin{array}{l}\text { Annual } \\
\text { per } \\
\text { capita } \\
\text { income } \\
\text { (PPP } \\
\text { dollars) } \\
2010\end{array}$ & $\begin{array}{l}\text { Forest } \\
\text { activity } \\
\text { area } \\
\text { (ha) } \\
2017\end{array}$ & $\begin{array}{l}\text { Agricultural } \\
\text { sector value in } \\
\text { thousands of } \\
\text { pesos } 2017\end{array}$ & $\begin{array}{l}\text { Livestock } \\
\text { sector value } \\
\text { in } \\
\text { thousands } \\
\text { of pesos } \\
2017\end{array}$ \\
\hline \multirow[t]{2}{*}{ Isthmus } & Mean & $8,275.21$ & 326.37 & $34,037,287.06$ & $86,024.25$ \\
\hline & Sum & & $13,381.34$ & $1,395,528,769.51$ & $3,526,994.17$ \\
\hline \multirow{2}{*}{$\begin{array}{l}\text { The } \\
\text { mountains }\end{array}$} & Mean & $7,931.80$ & - & $13,495,520.00$ & $229,644.45$ \\
\hline & Sum & & - & $13,495,520.00$ & $229,644.45$ \\
\hline \multirow{2}{*}{$\begin{array}{l}\text { The } \\
\text { Tuxtlas }\end{array}$} & Mean & $7,145.08$ & 381.26 & $13,108,926.00$ & 829.24 \\
\hline & Sum & & $1,525.03$ & $52,435,703.99$ & 316.97 \\
\hline \multirow[t]{2}{*}{ Olmec } & Mean & $8,943.32$ & 935.63 & $9,439,163.21$ & $857,697.23$ \\
\hline & Sum & & $23,390.85$ & $235,979,080.17$ & $21,442,430.83$ \\
\hline \multicolumn{2}{|c|}{ PapaloapanMean } & $6,604.65$ & 900.98 & $124,097,523.14$ & $472,698.22$ \\
\hline & Sum & & $4,504.88$ & $620,487,615.70$ & $2,363,491.08$ \\
\hline Sierra & Mean & $4,870.72$ & $1,892.70$ & $14,329,881.43$ & $12,193.46$ \\
\hline Norte & Sum & & $3,785.39$ & $28,659,762.85$ & $24,386.93$ \\
\hline
\end{tabular}

Table 4 Descriptors of the variables under study in the municipalities of the Isthmus

Source: Own elaboration based on INEGI (2015), SADER-SIAP (2018)

Even though the socioeconomic characteristics of the population as a whole, between the different demarcations (subregions) that make up the Isthmus, present cultural, productive and idiosyncratic similarities, there are elements towards the interior and exterior that develop differences for each one of the localities, populations rural and urban. Therefore, it is considered essential to link the indicators in Table 2 with the distribution of the employed population with at least 2 minimum wages (PO2SM) in the Isthmus demarcations. The population that is between a range of $67.61 \%$ and $84.50 \%$ with incomes less than 2 minimum wages is distributed among the regions of the Isthmus, Olmeca, Los Tuxtlas, Sierra Norte. On the other hand, livestock productions are located mainly on the coasts of both states (Veracruz and Oaxaca) of the region under study.

Four components were obtained that explain $73.66 \%$ of the variability of the information. On the other hand, with a Chisquare value and 105 degrees of freedom and a significance of $\mathrm{p}=0.000$, it is evident that it is not an identity matrix and the ACP study can be carried out with the variables established in Table 3; Furthermore, the Kaiser-Mayer-Olkin (KMO) value corresponds to 0.819 and therefore the model can be considered as acceptable.

Subsequently, using the stratification methodology of Dalenius and Hodges (1959), whose technique explores minimizing the variance, in this case, of the four components obtained. 
With this, heterogeneous groups are stratified between them and homogeneous among themselves. Table 5 shows the results of correlating the components between the variables of the municipal territories and the components.

Table 5 shows the correlations between the four main components generated and the variables under study. In this way it was possible to group those variables with high levels of correlations, both positive and negative. The first component is directly related positively to the illiterate population, occupied with 2 or less minimum wages and poverty; as the above increases, the levels of per capita income and education decrease. For this reason it has been called CP1 "Stratum with poverty, marginality and lag".

\begin{tabular}{|c|c|c|c|c|}
\hline \multirow{3}{*}{$\begin{array}{l}\text { Variables } \\
\% \text { of Population } \\
\text { aged } 15 \text { years or }\end{array}$} & \multicolumn{4}{|c|}{$\begin{array}{c}\text { Components } \\
01\end{array}$} \\
\hline & $.829 * *$ & 0.129 & -0.102 & 0.082 \\
\hline & & & & \\
\hline \multirow{2}{*}{$\begin{array}{l}\% \text { Occupants in } \\
\text { houses without }\end{array}$} & $.294 * *$ & .881 & 73 & \\
\hline & 0.009 & & & \\
\hline \multirow{2}{*}{$\begin{array}{l}\% \text { Occupants in } \\
\text { homes } \quad \text { without }\end{array}$} & & & & \\
\hline & & & & \\
\hline \multirow{2}{*}{$\begin{array}{l}\% \text { Occupants in } \\
\text { houses } \quad \text { without }\end{array}$} & 0.063 & .313 & .76 & \\
\hline & 0.5 & & & \\
\hline \multirow{2}{*}{$\begin{array}{l}\% \text { Occupants in } \\
\text { houses with dirt }\end{array}$} & .22 & .78 & & \\
\hline & & & & \\
\hline \multirow{2}{*}{$\begin{array}{l}\% \text { Population in } \\
\text { localities with less }\end{array}$} & $.466 * *$ & 0.1 & & \\
\hline & 00 & & & \\
\hline \multirow{2}{*}{$\begin{array}{l}\% \quad \text { Employed } \\
\text { population } \quad \text { with }\end{array}$} & $.82^{\prime}$ & & & \\
\hline & & & & \\
\hline \multirow{2}{*}{$\begin{array}{l}\text { Annual per capita } \\
\text { income }\end{array}$} & $-.922 * *$ & $-.250 *$ & & \\
\hline & 00 & & & \\
\hline \multirow{2}{*}{$\begin{array}{l}\text { Education Index } \\
2010\end{array}$} & $k *$ & -.26 & & \\
\hline & & & & \\
\hline \multirow{2}{*}{$\begin{array}{ll}\text { Income } & \text { index } \\
2010 & \\
\end{array}$} & $-.902 * *$ & $.306 * *$ & & \\
\hline & 00 & & & \\
\hline \multirow[t]{2}{*}{2010 health index } & $-.293 * *$ & $-.661 * *$ & & 01 \\
\hline & & & & \\
\hline \multirow[t]{2}{*}{ Poverty\% 2010} & $.885 * *$ & $.279 *$ & & \\
\hline & & & & 17 \\
\hline \multirow{2}{*}{$\begin{array}{ll}\text { Forest } & \text { activity } \\
\text { area } 2016 & \end{array}$} & 0.200 & & $.772 * *$ & \\
\hline & & & & 70 \\
\hline \multirow{2}{*}{$\begin{array}{l}\text { Total agricultural } \\
\text { value } 2017\end{array}$} & 0.040 & -0.1 & & \\
\hline & 0.728 & & & 0.000 \\
\hline \multirow{2}{*}{$\begin{array}{l}\text { Total livestock } \\
\text { value } 2017\end{array}$} & & -0.078 & & \\
\hline & 0.328 & 0.497 & 0.282 & 0.000 \\
\hline
\end{tabular}

Table 5 Correlations between the components of the ACP model

Source: Own elaboration based on CONAPO (2015b), INEGI (2015), SADER-SIAP (2018)

Pearson correlation. Sig. (Bilateral) $*<0.001$, $* *<0.05$
Subsequently, the variables positively correlated in the second component are that population with houses without drainage or toilets, without electricity and with a dirt floor. As these increase, the health index decreases; therefore, CP2 "Stratum with housing and health deficiencies" would be identified. Regarding the third component, the positively related variables are the occupants without piped water and also land areas with forestry activity, that is, CP3 "Stratum with lack of water and forestry sector". Finally, the fourth component groups a positive relationship between the population living in rural areas and agricultural production, on the contrary, as these increase the value of livestock production decreases. This will be called CP4 "Stratum with activities in the livestock, agricultural and rural sectors".

Likewise, it is observed that as the level of the stratum increases, social problems increase, that is, the population that lives with deprivation of poverty, marginality and social backwardness increases according to the territories with social vulnerability. It is clear that the relationship between more illiteracy and lower income per salary shows a relationship in reduction of the well-being of families and the human development index of the region. In short, a small number of municipalities with characteristics with low levels of marginalization problems are observed (See Annex 2).

\section{Conclusions}

Prospera is an ambitious federal government program whose purpose is to fight poverty head-on, seeking to improve food and nutrition; health and self-care; education and support with scholarships for young people; financial, labor and productive inclusion; social participation; right of audience; empowerment in the female sector, mainly. However, in light of the methodology used, it can be inferred that not all the good intentions established in the Social Program are necessarily fulfilled.

The results of the PSM model demonstrate that the Prospera Program shows a weakness in the generation of autonomous (labor) income for the states of Veracruz, Oaxaca in the Isthmus region. 
This reality shows an important weakness of the Program since in these territories it has not been possible to meet its general objective. In this context, the need for government entities (federal, state and municipal) to establish open and transparent dialogues to establish formal commitments that help to generate cross-sectional and multidisciplinary information related to the beneficiaries of the program is essential, in order to reorient the efforts. It is pertinent to develop a critical analysis of prospecting, design and implementation of public policy linking academia, companies, the government sector and international institutions dedicated to social development.

Government actions and programs must integrate social, environmental, economic (labor), cultural, and political aspects, among others, into the design; in such a way that the Program is accompanied by strategies to promote added value to local productive activities, establishing synergies for gender empowerment and incubation of paid jobs that allow generating well-being in society. Likewise, it is required to prepare technological route maps to prospect innovative development among the beneficiary population and in their territories, fundamentally in the Isthmus region and to reverse, where appropriate, the economic dependence on the monetary support of the Program that may be operating in the region, that is, reduce incentives that have adverse effects on the Program objective.

In addition, it is essential to strengthen the activities of targeting and management of social policies that are built and developed from the Secretary now called "Secretariat of Wellbeing", previously Secretary of Social Development, using all the account information on the most vulnerable population. In short, it is essential to generate debates for the construction in the design of public policies operated in the Prospera program, which will allow us to reconsider its sustainability and comprehensive socioeconomic development, allowing the beneficiaries to obtain better living conditions, as well as promoting greater integration. Social.

\section{Acknowledgments}

Project 291766. Development of technological and innovation strategies to promote a logistics platform as a trigger for regional development in the Isthmus of Tehuantepec. Institutional Fund for Regional Development for Scientific, Technological and Innovation Development (FORDECYT) - CONACYT.

\section{References}

Abadie, A., Drukker, D., Herr, J. L., \& Imbens, G. W. (2004). Implementing matching estimators for average treatment effects in Stata. The Stata Journal, 4(3), 290-311.

Banco Mundial. (2018a). La pobreza y la prosperidad compartida 2018: Armando el rompecabezas de la pobreza. https://www.bancomundial.org/es/research/brie f/poverty-and-shared-prosperity-2018-piecingtogether-the-poverty-puzzle-frequently-askedquestions

Banco Mundial. (2018b). Transferencias monetarias condicionadas para familias pobres: Una herramienta eficiente para combatir la pobreza e incrementar el capital humano. Resultados Del BIRF.

Barro, R. J. (1991). Economic growth in a cross section of countries. The Quarterly Journal of Economics, 106(2), 407-443.

Cámara de Diputados. (2004). Ley general de desarrollo social.

Cameron, A. C., \& Trivedi, P. K. (2005). Microeconometrics: methods and applications. Cambridge university press.

Cerón, J., \& Hernández, M. (2017). Análisis del impacto del Programa Oportunidades en el ingreso autónomo de sus beneficiarios. Economía Informa, 406, 62-79.

Cerulli, G. (2015). Econometric evaluation of socio-economic programs. Advanced Studies in Theoretical and Applied Econometrics Series, 49.

Chen, S., Mu, R., \& Ravallion, M. (2006). Are there lasting impacts of aid to poor areas? Evidence from Rural China. Research Brief. Washington, DC: World Bank. 
CONAGUA. (2015). Vulnerabilidad Social, Económica y Ambiental por municipio.

CONAPO. (2015a). Consejo Nacional de Población. Índice de Marginación por Entidad Federativa y Municipio, 2015. Conapo. https://www.gob.mx/conapo

CONAPO. (2015b). Marginación municipal. http://www.conapo.gob.mx/

CONEVAL. (2016). Medición de la pobreza Estados Unidos Mexicanos. In Medición de la pobreza (Vol. 339).

CONEVAL. (2018a). Informe de evaluación de la política de desarrollo social. Consejo Nacional de Evaluación de La Política de Desarrollo Social. https://www.coneval.org.mx/Evaluacion/IEPS M/IEPSM/Documents/RESUMEN_EJECUTIV O_IEPDS2018.pdf

CONEVAL. (2018b). Metodología para la medición multidimensional de la pobreza en México. In Consejo Nacional de Evaluación de la Política de Desarrollo Social.

Dalenius, T., \& Hodges Jr, J. L. (1959). Minimum variance stratification. Journal of the American Statistical Association, 54(285), 88101.

Echeverri, R., Portilla, M., Rodríguez, A., \& Sepúlveda, S. (2003). Desarrollo rural sostenible. Enfoque territorial. Sinopsis 2003, 180.

Farrell, G., Thirion, S., \& Soto, P. (1999). La competitividad territorial: Construir una estrategia de desarrollo territorial con base en la experiencia de leader (De la serie: Innovación en el Medio Rural, Cuaderno N. o 6-Fascículo 1). Bruselas: Observatorio Europeo Leader.

Gonzalo, L., Jiménez, R., \& Fiorella, M. (2018). Pobreza y derechos sociales en México (UNAM (ed.)). Consejo Nacional de Evaluación de la Política de Desarrollo Social.

Hanushek, E. A., \& Kimko, D. D. (2000). Schooling, labor-force quality, and the growth of nations. American Economic Review, 90(5), 1184-1208.
INEGI-ENIGH. (2016). Encuesta Nacional de Ingresos y Gastos de los Hogares. https://www.inegi.org.mx/programas/enigh/nc/2 $016 /$

INEGI. (2015). Instituto Nacional de Estadística y Geografía. Módulo de condiciones socioeconómicas (MCS), 2015. Módulo de Condiciones Socioeconómicas 2015.

https://www.inegi.org.mx/programas/mcs/2015/

Jalan, J., \& Ravallion, M. (2003). Estimating the benefit incidence of an antipoverty program by propensity-score matching. Journal of Business \& Economic Statistics, 21(1), 19-30.

Khandker, S., B. Koolwal, G., \& Samad, H. (2009). Handbook on impact evaluation: quantitative methods and practices. The World Bank.

PNUD. (2015). Informe de Desarrollo Humano Municipal 2010-2015 Transformando México desde lo local.

Raczynski, D. (1995). Estrategias Para Combatir la Pobreza en América Latina: Diagnóstico Y Lecciones de Política: Informe Comparativo Regional (CIEPLAN-BID (ed.); Vol. 193). Departamento de Desarrollo Económico y Social, Banco Interamericano de Desarrollo.

Ramcharan, B. (2004). Los derechos humanos y la reducción de la pobreza: Un marco conceptual. In Naciones Unidas para los Derechos Humanos. ONU.

Rosenbaum, P. R., \& Rubin, D. B. (1983a). Assessing sensitivity to an unobserved binary covariate in an observational study with binary outcome. Journal of the Royal Statistical Society: Series B (Methodological), 45(2), 212218.

Rosenbaum, P. R., \& Rubin, D. B. (1983b). The central role of the propensity score in observational studies for causal effects. Biometrika, 70(1), 41-55.

Rosenbaum, P. R., \& Rubin, D. B. (1984). Reducing bias in observational studies using subclassification on the propensity score. Journal of the American Statistical Association, 79(387), 516-524. 
SADER-SIAP. (2018). Servicio de Información Agralimentaria y Pesquera de la Secretaría de Agricultura y Desarrollo Rural. https://www.gob.mx/siap

Secretaria del Bienestar. (2019). Prospera.

Programa De Inclusión Social. . antes Secretaria de Desarrollo Social. https://www.gob.mx/prospera/documentos/quees-prospera 